\title{
Ruminal acidosis: strategies for its control
}

\author{
Esaúl Jaramillo-López, Mateo F. Itza-Ortiz*, Gwendolyne Peraza-Mercado, \\ José M. Carrera-Chávez
}

\begin{abstract}
Ruminal acidosis in ruminants is a metabolic disorder of gastrointestinal origin that occurs in animals with a high feed intake of cereal grains diets, which affect the performance. According to clinical manifestations it can be classified as: a) acute lactic acidosis with prolonged exposure to ruminal $\mathrm{pH} \leq 5.0$, triggering a systemic acidosis, with clinical manifestations and changes in biochemical patterns, starting the first twelve hours of ruminal acidosis and it takes 48 to 120 hours to reestablish, b) subacute ruminal acidosis (SARA), it has no clinical manifestations, rumen $\mathrm{pH}$ decreases in a range of 5.5 to 5.0 and is held for 111 to 180 minutes in 24 hours, this decrease causes an imbalance in the ruminal metabolism, as well as the fluid balance. Ruminal acidosis can be prevented by adding sodium bicarbonate to the ration, or zootechnic additives such as Saccharomyces cereviseae and Megasphaera elsdenii as well as essential oils (cinnamaldehyde and eugenol). It is also important to consider the forage/concentrate ratio, the forage particle size, the NDF content of the ration, as well as the cereal's rate of degradation in the rumen. The objective of this review was to address the ruminal acidosis pathophysiology, its effects on animal welfare and control strategies to minimise the detrimental impact on animal production.
\end{abstract}

Key words: metabolic disorder, ruminal subacute acidosis.

RESUMEN. La acidosis ruminal es un trastorno metabólico de origen digestivo, que se presenta en los rumiantes al ingerir dietas altas en granos de cereales, y que afecta el rendimiento productivo. Según sus manifestaciones clínicas se clasifica en: a) acidosis láctica aguda en la que hay una exposición prolongada a un $\mathrm{pH}$ ruminal $\leq 5,0$, lo que desencadena una acidosis sistémica con manifestaciones clínicas, así como cambios en los patrones bioquímicos que se inician en las primeras doce horas de la acidosis ruminal y tardan de 48 a 120 horas en restablecerse, y b) acidosis subaguda ruminal (ASR), donde no hay manifestaciones clínicas, el $\mathrm{pH}$ del rumen disminuye en un rango de 5,5 a 5,0 y se mantiene durante 111 a 180 minutos en 24 horas, este descenso provoca un desequilibrio tanto en el metabolismo ruminal como en el balance de líquidos. La acidosis ruminal se puede prevenir por la adición de bicarbonato de sodio, aditivos zootécnicos como la Sccharomyces cerevisiae y Megasphaera elsdenii, y aceites esenciales (cinamaldehído y eugenol). Es importante considerar la relación forraje/concentrado así como el tamaño de partícula del forraje, el contenido de FND de la ración, y la degradación del grano de cereal en el rumen. El objetivo de la presente revisión fue abordar la fisiopatología de la acidosis ruminal, los efectos que esta causa en el bienestar animal y las estrategias para su control, para minimizar su impacto detrimental en la producción animal.

Palabras claves: trastorno metabólico, acidosis subaguda ruminal.

\section{INTRODUCTION}

The functional health of the reticle-rumen is an essential requirement for productive behavior, encompassing livestock health and animal welfare (van Vuuren et al 2012). Under modern animal production systems, ruminants are fed high grain diets to maximize energy consumption and hence productivity (Oba and Wertz-Lutz 2011). However, ruminants are adapted to digest and metabolise forage diets (Krause and Oetzel 2006). Intensive fattening systems require rations containing high proportion of grains (corn, barley or sorghum), that upon reaching the rumen break down quickly producing large amounts of lactic acid that predispose to metabolic disorders (Smith 1998). One of the limitations in intensive ruminant production is acute ruminal acidosis and subacute acidosis ruminal (SARA); the latter is difficult to diagnose, because the only thing that can be observed is a decrease in feed consumption

Accepted: 20.06.2017.

Universidad Autónoma de Ciudad Juárez, Chihuahua, México.

*Corresponding author: MF Itza-Ortiz; Av. Plutarco Elías Calles \#1210, Ciudad Juárez, Chihuahua, México; mateo.itza@ uacj.mx and consequently an increase in feedlot time and increased production costs.

The objective of this review was to address the ruminal acidosis pathophysiology, its effects on animal welfare and control strategies to minimise the detrimental impact on animal production.

\section{ACIDOSIS PATHOPHYSIOLOGY}

Ruminant lactic acidosis is a digestive disorder caused by the sudden intake of easily digestible carbohydrates in the rumen, mainly cereal grains (Haji-Hajikolaei et al 2006, Aschenbach et al 2011). Cereal starch is rapidly degraded in the rumen to become lactic acid at a very high rate that exceeds the rumen absorption capacity (Haji-Hajikolaei et al 2006). The lactic acid production is affected by the substrate, being higher for wheat than for maize (Lettat et al 2010). The accumulation of this acid in the rumen, favours $\mathrm{pH}$ decrease (Wenping et al 2007, Aschenbach et al 2011). The absorption of lactic acid in the circulatory system, alters the systemic and ruminal acid-base balance, as well as the water balance and food intake (Nocek 1997).

Food intake and chewing during ingestion and rumination, has a great effect on the acid-base balance of the 
ruminal fluid. The characteristics of the intake associated with decreased ruminal $\mathrm{pH}$ are: high intake of dry matter in a short period of time, promoting increased production of acid in the rumen, because saliva production decreases along with chewing time. The acid-base balance in the rumen requires time synchronisation between the production of acid, neutralisation of this through saliva and absorption through the ruminal epithelium (Gonzalez et al 2012). Giger-Reverdin et al (2006) mention that saliva production increases along with the chewing rate per kilogram of dry matter, and with the increase of saliva production there is a greater buffer input into the rumen increasing the $\mathrm{pH}$ to 5.94 .

The primary system to counteract the development and progression of acidosis is the $\mathrm{HCO}_{3}$ - reaching the rumen via the saliva, which is the medium used to maintain stable ruminal $\mathrm{pH}$. Estimates in high producing dairy cows indicate that $\mathrm{HCO}_{3}$ - is introduced into the rumen approximately in equal parts via saliva and secretion through the ruminal epithelium. Most secreted $\mathrm{HCO}_{3}$ - binds directly to the absorption of short chain VFA (Volatile fatty acids), which are absorbed by lipophilic diffusion in the ruminal epithelium (figure 1), both $\mathrm{HCO}_{3}$ - secretion and VFA absorption, are the key to maintaining stable the ruminal acid-base balance (Aschenbach et al 2011, Dijkstra et al 2012).

Volatile Fatty Acid produced during microbial fermentation should be neutralised o eliminated from the rumen to prevent ruminal $\mathrm{pH}$ decrease. VFA are weak acids and establish a balance between acid ( $\mathrm{H}$ acid) and the base conjugate (acid-). Ruminal pH depends on the HendersonHasselbach balance $\mathrm{pH}=\mathrm{pKa}+\log \left[\left(\mathrm{acid}^{-}\right)(\mathrm{H} \text { acid })^{-1}\right]$ where $\mathrm{pKa}$ is the negative logarithm of the acid constant, Ka. Lactic acid has a lower pKa (3.80) than acetic acid ( $\mathrm{pKa}=4.76)$, propionic acid $(\mathrm{pKa}=4.78)$ or butyric acid $(\mathrm{pKa}=4.82)$. Due

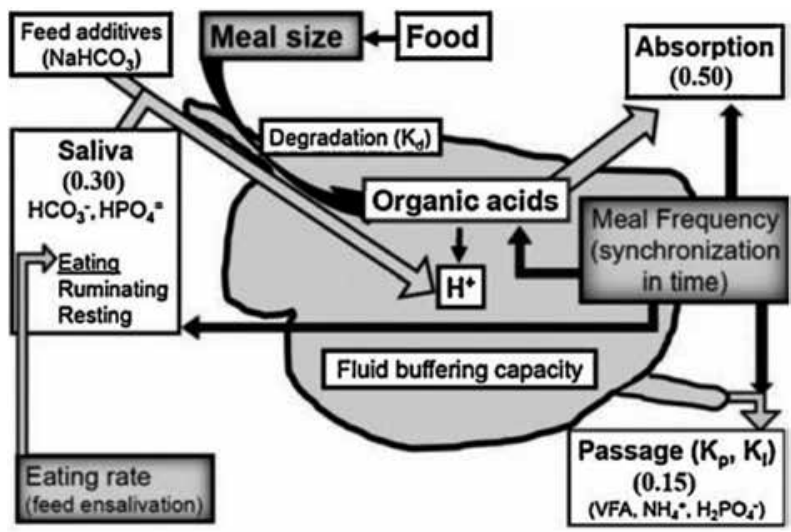

Figure 1. Factors involved in acid-base balance in the ruminal fluid. The main routes of elimination of rumen acids is absorption, neutralisation by buffer substances in saliva and the passage of food and liquid substances from rumen to the small intestine. Eating behaviour affects time synchronisation between the production of acids and food elimination (Gonzalez et al 2012). to the fact that the three major VFA, acetic, propionic and butyric acids have a similar $\mathrm{pKa}$ value, the production of 1 mole of butyric acid from 1 mole of hexose can reduce the $\mathrm{pH}$ relatively less than the production of 2 moles of propionic or acetic acid from 1 mole of hexoses. During ruminal acidosis, lactic acid concentration is low but as the $\mathrm{pH}$ drops below 5.7, the rate of lactic acid formation exceeds the absorption capacity, mainly through fermentation by acid user microorganisms, therefor lactic acid is accumulated in the rumen, which causes a drastic decrease in $\mathrm{pH}$ (Dijkstra et al 2012).

Rumen lactate accumulates in two isomers: D-lactate produced in lower amount than L-lactate, being larger the absorption of the first one; an increase of D-lactate ruminal absorption to the blood system that can exhaust the buffering capacity of $\mathrm{HCO}_{3}$ - and produce a generalised acidosis (Harmon et al 1985). The ruminal microbiome is determined by the type of feed ingested by the ruminant, and rumen bacteria (Ruminococcus) predominate at $\mathrm{pH}$ 6.8 in cellulolytic diets.

However, increasing the concentrate in the diet and reducing the forage modifies the microbial population change the ruminal $\mathrm{pH}$ (5.5 and 6.5) and increase the amylolytic bacteria such as Streptococcus bovis (Lean et al 2007).

Health disorders, which result from acidogenic diets are classified as acute acidosis and SARA, this ranking is based on the degree of $\mathrm{pH}$ ruminal decrease (Aschenbach et al 2011).

Acute ruminal acidosis is a metabolic state defined by the decrease of blood $\mathrm{pH}$ and bicarbonate (Hernandez 2014), the ruminal $\mathrm{pH}$ is less than 5.0 and the animals have depression, loss of appetite, reduced rumination, diarrhea and dehydration (Bolton and Pass 1988, Laskoski et al 2014); microbial metabolism and food digestion are also affected, inflammatory processes occur and milk fat decreases (Dijkstra et al 2012).

Subacute ruminal acidosis (SARA) is a common health and production problem occurring en rumiants and is often triggered by low ruminal $\mathrm{pH}$ from a low-fiber diet (Zhao et al 2011). Subacute ruminal acidosis is defined as the time that rumen $\mathrm{pH}$ drops from 5.5 to 5.0, and is maintained in that range for 111 to 180 minutes in a 24 hour period (Krause and Otzel 2006, Rustom et al 2006, Penner et al 2010, Castillo-Lopez et al 2014). SARA is a state of temporary disruption of rumen amending fermentation patterns; however, the intensity and duration are not sufficient to cause immediate clinical signs (Nocek 1997, Maulfair et al 2013). Technological advances have greatly improved the understanding of the mechanisms of interaction between the fermentability of the diet, the intake and rumen $\mathrm{pH}$ (Penner et al 2009). The low ruminal $\mathrm{pH}$ characteristic of SARA may be due mainly to changes in the buffering capacity of carbonic acid and VFA. The effect of a long term acid diet over the alkaline reserve in blood suggests a long recovery period which is reflected in the ruminal parameters (Brosard et al 2003). 
Another consequence of the reduction in $\mathrm{pH}$ is the decrease in digestible organic matter ingested and VFA production, which may be part of the rumen ecosystem self-regulatory mechanisms against ruminal acidosis (Calsamiglia et al 2008). SARA is not only a pH dependent disorder, but is the result of changes in secondary microbial population and the type of diet fed (Calsamiglia et al 2012).

\section{CONSEQUENCES ON HEALTH, ANIMAL WELFARE AND PRODUCTION}

Animal welfare implies that the animal will develop physically and mentally in good conditions, and that nutritional, social, management, health and comfort factors do not adversely affect production (Hewson 2003, Carenzi and Verga 2009).

Health disorders which result from acidogenic diets, in acute acidosis are based on the degree of $\mathrm{pH}$ ruminal decrease (Garret et al 1999, Aschenbach et al 2011, Kleen and Cannizzo 2012, Minuti et al 2014). The presence of large amounts of lactic acid in the ruminal fluid and its rapid entry into the blood system demand a great challenge from the buffering capacity of the ruminal intake and body fluids. Lactic acid remaining in the digestive system also contributes to lactic acidosis syndrome (Nocek 1997), affects metabolism (Galyean and Rivera 2002), change the population of microorganisms, rumen motility and the systemic fluid balance. As the $\mathrm{pH}$ of rumen intake severely diminishes towards $\mathrm{pH}$ 5.0, the amplitude and frequency of rumen contractions progressively decrease until it reaches rumen stasis (Huber 1976).

Three mechanisms may be responsible for ruminal atony after acidification of the rumen: 1) the effect of hydrogen ion on receptors in the gastrointestinal system; 2) central inhibition by acid absorption and 3) inhibition by amines or absorbed toxins (Huber 1976). Ruminal atony is manifested as poor appetite, because if the rumen is not functioning, degradation and nutrient absorption through the ruminal epithelium is not performed, so animals stop eating (González et al 2012).

In acute acidosis the rumen epithelium alters its function and structure; with diets high in grains the rumen papillae show a large detachment of corneum stratum and affects the adhesion of cells (figure 2) with the appearance of large gaps between cells across the layer (Steel et al 2009). As the ruminal epithelium is damaged, an inflammatory process that causes pain in ruminants is generated and manifests as the clenching of teeth, loss of appetite and ruminal atony (Odongo et al 2006 ${ }^{\mathrm{a}}$ ).

The ruminal barrier is responsible for maintaining the concentration gradient required for the absorption of ions, prevent translocation of lipopolysaccharides and other toxins, as well as bacterial entry into the systemic circulation. Rumen acidosis is the most important factor that can damage the rumen wall (Penner et al 2011, Plaizier et al 2012), decreasing the count of papillae on the ventral sac of the rumen (figure 3) (Odongo et al $2006^{\mathrm{a}}$ ). Pharmacologically active amines have been detected during the intake in rumen from animals with acidosis, such as histamine that comes from histidine decarboxylation when rumen intake approaches $\mathrm{pH} 5.0$ or less (Huber 1976). The histamine release in the rumen and its absorption into the circulatory system, allow these compounds to reach the extremities where they cause inflammatory reactions such as laminitis, which causes pain when moving.

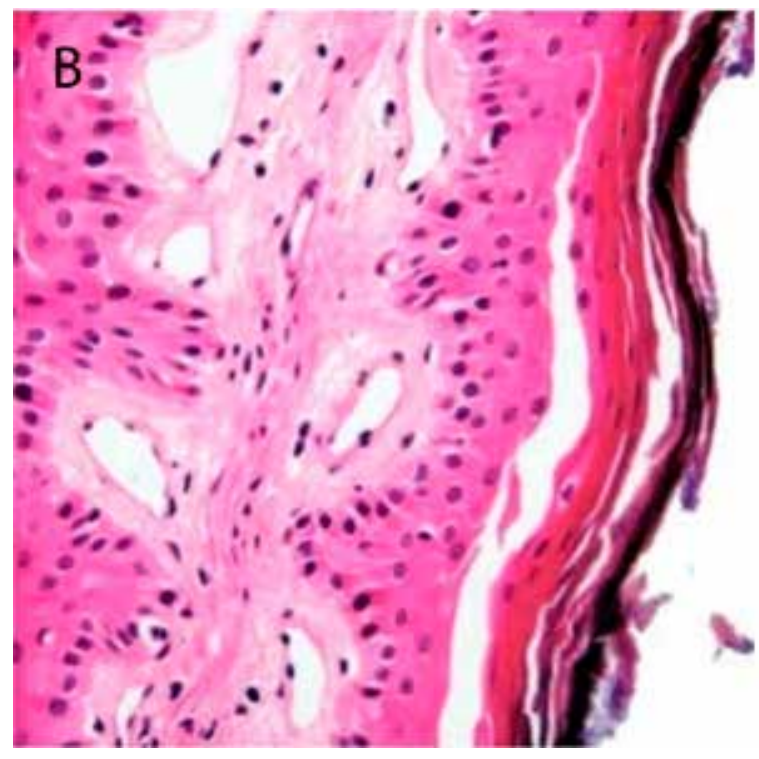

Figure 2. Photograph of two ruminal papillae: A) Ruminal papilla of a diet high in forages, with the corneum and granular stratum intact. B) Rumen papilla of a diet high in grains, where swelling of the corneum stratum and demarcation of cells throughout the epithelial layers is observed (Steel et al 2009). 

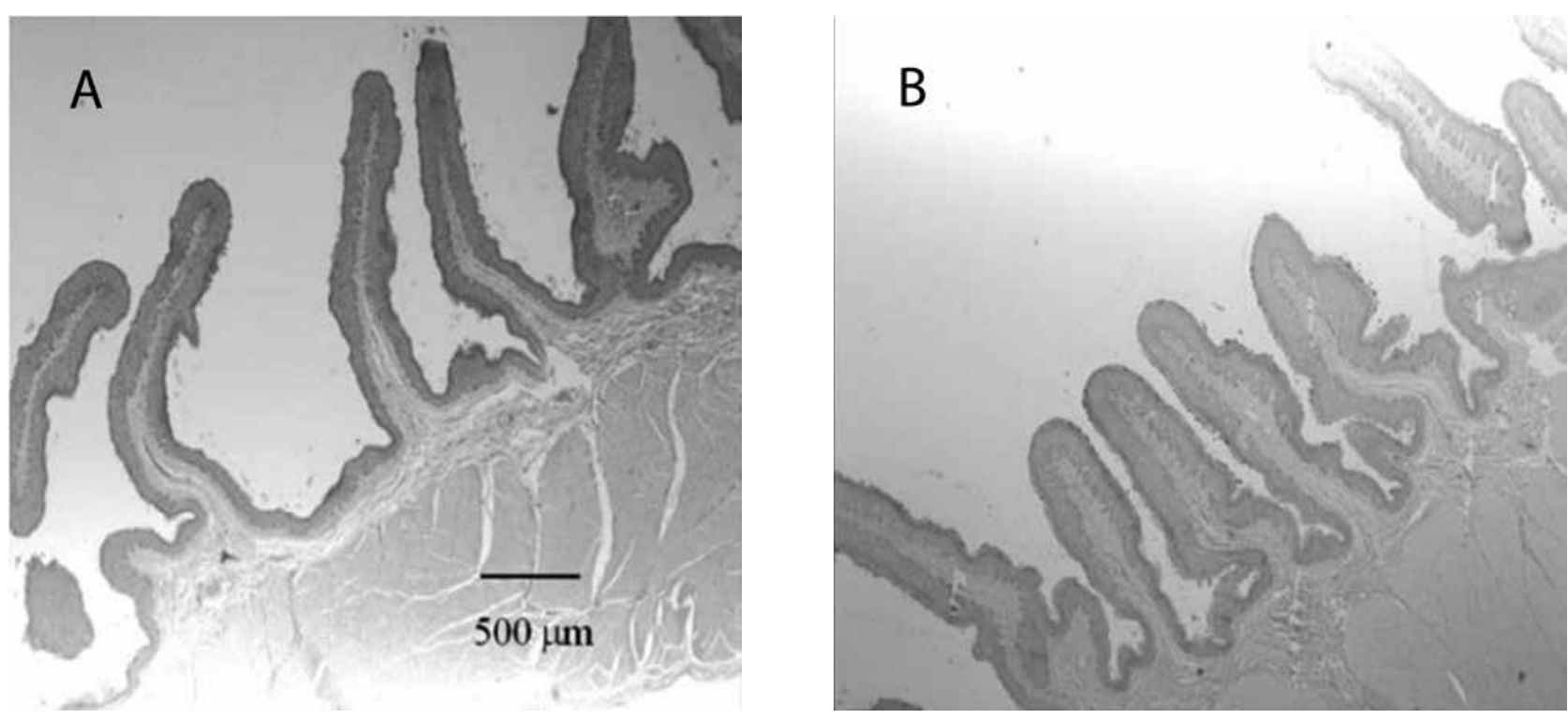

Figure 3. Ruminal papillae morphology of lambs on two diets. A) High in grains; B) Control group (Odongo et al $2006^{\mathrm{a}}$ ).

Another consequence of ruminal acidosis is that fluid balance is affected. The animals that develop ruminal acidosis may experience diarrhea and dehydration, consequently there is fluid loss and therefore increases the hematocrit, decreasing the elasticity of the skin. The rumen fluid becomes hypertonic to plasma, therefore water is absorbed from the blood system into the rumen, and consequently the water lost in the body and blood enters the rumen. Rumen osmolarity increases from 255 to 401 milliosmoles. Lactic acid is responsible for the increase (61\%) of the osmolarity. The fluid loss through faeces is high during diarrhea and occurs in the time period when the rumen motility is inhibited, suggesting a net movement of body water towards the intestine (Huber 1976).

Prolonged exposure to a low ruminal $\mathrm{pH}$, results in a systemic acidosis which imposes a chronic stress on the physiological mechanisms of the animal and the ability to maintain the acid-base balance (Odongo et al 2006 ${ }^{\mathrm{b}}$ ). Chronic metabolic acidosis alters the acid-base parameters (Haji-Hajikolaei et al 2006) and the amino acid concentration in blood (Odongo et al 2006 ${ }^{\mathrm{b}}$ ).

In the SARA, dry matter intake decreases, which favors an imbalance in the ruminal metabolism, having a lower nutrient uptake (Kleen and Cannizzo 2012). There is a possible link between the decrease in rumen $\mathrm{pH}$ and voluntary feed intake (Fulton and Klopfenstein 1979).

To measure the blood acid-base balance in acute acidosis and SARA, the Henderson-Hasselbach equation is used, wherein the ratio of bicarbonate and carbon dioxide must decrease as blood $\mathrm{pH}$ decreases; however, when the tension of carbon dioxide from blood is increased and blood $\mathrm{pH}$ is decreased, the respiratory center is stimulated, leading to an increase in $\mathrm{CO}_{2}$ removal and thus the buffer is restored to the desired level of 20:1. Therefore, as the input of lactic acid to blood increases, carbon dioxide tension increases, respiratory rate decreases, blood pressure decreases and pH quickly drops (Huber 1976). The acute decrease in ruminal $\mathrm{pH}$ is associated with the decrease of blood $\mathrm{pH}$ (Brown et al 2000), the increase of total lactic acid in the rumen fluid and blood, the increase of blood levels of sodium and inorganic phosphorus, and the decrease of potassium and calcium levels (Patra et al 1991).

Biochemical pattern changes initiate within the first twelve hours of ruminal acidosis and take 48 to 120 hours to reset (Patra et al 1991).

\section{STRATEGIES TO REDUCE RUMINAL ACIDOSIS}

\section{BUFFER SUBSTANCE}

A buffer is a material that when is present in an aqueous solution causes an effective resistance to changes in $\mathrm{pH}$ of the solution, when it is strongly acid or base is added. For a compound to act as a buffer the following requirements must be met: 1) must be soluble in water; 2) must be a weak acid or base; 3 ) the equivalence point (pK) must be near to the physiological $\mathrm{pH}$ of the system to buffer. Buffering agent requirements in the diet are based on the buffer capacity of the saliva secreted, buffer capacity of the food and diet acidity (Erdman 1998).

Buffer substances supplementation can be a way to limit the adverse effects of ruminal acidosis and can be added in whole rations from 0.5 to $2.5 \%$. The following compounds have been used: sodium bicarbonate, disodium carbonate, magnesium oxide, potassium carbonate and anhydrous limestone (Gastaldello et al 2013). In dairy cows, a meta-analysis of 40 publications of the following buffer substances was made: sodium bicarbonate, disodium 
carbonate, magnesium oxide, potassium monoanhydro carbonate, monosodium carbonate and magnesium oxide; the dry matter intake was improved in $0.15 \mathrm{~kg} / \mathrm{day}$, milk production $0.52 \mathrm{~kg} /$ day and fat percentage $0.15 \%$. Rumen $\mathrm{pH}$ increased by 0.07 units, so buffer substances are more efficient in SARA (Meschy et al 2004).

The addition of sodium bicarbonate results in the release of $\mathrm{CO}_{2}$ from the solution and eventually from the rumen via belching. This process directly neutralises ruminal acidity. The extent to which the process proceeds depends on the partial pressure of $\mathrm{CO}_{2}$ in the gas phase, the $\mathrm{pH}$ and a constant (7.74), according to the Henderson-Hasselbalch equation: $\mathrm{pH}=7.74+\log \left[\left(\mathrm{HCO}_{3}^{-}\right)\right] / \mathrm{CO}_{2}$ pressure in atmospheres (Kohn and Dunlap 1998).

Sodium bicarbonate can increase the osmolarity, water consumption, the production of saliva and therefore increases the dilution rate of the VFA in the rumen and the passage rate of the liquid phase (Gastaldello et al 2013). Sodium bicarbonate acts in two ways: as a source of sodium to meet the requirements and help provide a positive balance in the cation-anion ratio in dairy cows (Hu and Murphy 2005, Lean et al 2007) and as a buffer in diets based on corn silage (200 to $300 \mathrm{~g} / \mathrm{animal} /$ day) (Lean et al 2007). In addition to baking soda, sodium sesquicarbonate in the diet can be used and its effect is more pronounced on diets that are used at the end of lactation (Clark et al 2009). The addition of sodium bicarbonate in dairy cows is limited by the elimination of sodium through urine and subsequent alkalization of the soil (Rauch et al 2012). In weaned lambs fed barley grain and a supplement of granulated protein, sodium bicarbonate did not buffer the $\mathrm{pH}$ of the ruminal fluid, nor improved dry matter intake and daily weight gain, but modified the fermentation patterns towards greater ratio of acetate to propionate (Boda 2004, Askar et al 2011).

Another buffer used in the prevention of ruminal acidosis is limestone; in lambs the addition of $1.3 \%$ in the diet maintained rumen $\mathrm{pH}$ between 5.7 and 6.0 and dry matter digestibility improved, so it can be used in diets with high concentrations of corn (Gastaldello et al 2013). For beef cattle in finalisation (Anderson 1982) three levels of limestone 1, 2 and $4 \%$ were used. The productive performance was better in diets with 1 and $2 \%$, higher levels inhibited appetite and reduced efficiency. The addition of magnesium oxide $0.05 \%$ in the concentrate improved daily gain, feed intake and final weight of Lori-Bakhitiari lambs in finalisation (Hashemi et al 2012).

\section{ZOOTECHNICAL ADDITIVES AND VACCINES}

In 2003 the European Union banned the use of antibiotics as additives in food for domestic species. The old category of 'microorganisms' and the term 'probiotics' disappears for being too general and is replaced by that of 'zootechnical additives' in which microorganisms and enzymes are included. One of the points of interest of the use of zootechnical additives in ruminants, is to control the accumulation of lactate in the rumen and stimulate the synthesis of propionate; the most commonly used in ruminants are the yeasts (Saccharomyces cerevisiae and boulardii) as well as Aspergillus niger and oryzae (Caja et al 2003).

In the supplementation of live yeast to lactating cows ( 5 $\mathrm{g}$ /day) equivalent to $10^{10} \mathrm{CFU}$ of Saccharomyces cerevisiae, the average ruminal $\mathrm{pH}$ was higher in cows supplemented than in those who received no yeast (6.05 vs 5.49). The effect of yeast supplementation on ruminal $\mathrm{pH}$ is evident one week after the supplementation initiated (Bach et al 2007). Yeast supplementation is effective in reducing the amount of time in which rumen $\mathrm{pH}$ is below 5.8 (Vyas et al $\left.2014^{\mathrm{a}}\right)$. The use of yeast in ruminants reduces subclinical acidosis (Bach et al 2007, Vyas et al 2014ª), however, the supplementation of yeast had no effect on the $\mathrm{pH}$ during the experimental induction of acute acidosis in cattle (Vyas et al 2014 ). Uyeno et al (2017) suggest that effects of supplementing live yeast to cows in mid-to-late lactation may be limited to microbial composition and fermentation characteristics in the rumen.

The administration of Megasphaera elsdenii $10^{11}$ CFU, strain NCIMB 41125 in sheep, can control ruminal acidosis during the transition period from forage to grain, because Megasphaera elsdenii is able to use the ruminal lactic acid and keeps it constant at $<10 \mathrm{mmole} / \mathrm{L}$ (Henning et al 2010 a Henning et al $2010^{\mathrm{b}}$ ).

Not only yeasts are used in the control of ruminal acidosis, polyclonal antibodies preparation (PAP) can also be used which are a mixture of immunoglobulins secreted against a specific antigen that may be effective in reducing the incidence of acidosis during transition from high forage diets to high grain diets. The major target bacteria for the PAP is Streptococcus bovis, main cause of ruminal acidosis, but is not relevant in practice (Blanch et al 2009). Intramuscular immunisation against Streptococcus bovis strain SB-5 and a booster dose at 28 days, improved ruminal $\mathrm{pH}$ and dry matter intake, reduced the incidence of diarrhea and increased the blood cell pack volume in sheep fed a ration containing $90 \%$ wheat grain and $10 \%$ alfalfa (Shu et al 2000). Besides Streptococcus bovis in ruminal acidosis research, the importance of Pediococcus acidilactici has also been demonstrated (Cobos et al 2011).

\section{ESSENTIAL OILS AND ANTIOXIDANTS}

There is a potential benefit for using some plant extracts to improve the profile of ruminal fermentation in beef production systems when the ruminal $\mathrm{pH}$ is low $(\mathrm{pH}$ 5.5). Allium sativa, Capsicum anuum, Yucca schidigera and Cinnamonum cassia extracts alter the fermentation of rumen microorganisms in favour of propionate (Cardozo et al 2005). In vitro studies with essential oils (EO) proved that microbial activity is modified in the rumen and can be a natural alternative to modify the rumen microbial 
fermentation. The EO Syzygum aromaticumm at a dose of $500 \mathrm{mg} / \mathrm{L}$ increases the total of VFA (Castillejos et al 2008). Likewise, the mixture of cinnamaldehyde $(0.18$ $\mathrm{g} / \mathrm{d})$ and eugenol $(0.09 \mathrm{~g} / \mathrm{d})$ proved to be useful as food additives in beef heifers fed high grain diets, by modifying the rumen microbial fermentation (Cardozo et al 2006). The effect of a garlic oil chemical compound, propyl-propane thiosulfonate (PTSO), in an effective dose between 50 a $100 \mathrm{mg} / \mathrm{L}$ modify ruminal fermentation in a direction consistent with higher propionate molar proportion (Foskolos et al 2015).

The general term vitamin $\mathrm{E}$ is used to designate a group of eight natural species of tocopherols and tocotrienols ( $\alpha, \beta, \gamma$ and $\delta$ ) (Sayago et al 2007). The main function of vitamin $\mathrm{E}$ is to be an antioxidant that reacts with free radicals soluble in lipid membranes (Cespedes 2012). In the ruminal lactic acidosis there is an oxidative stress (Kirbas et al 2014) so vitamin E can be used in the prevention of the harmful effects of lactic acidosis, because it helps keep the acid-base status, at mitochondrial level, as demonstrated (Morán et al 2013) in feedlot lambs using $0.6 \mathrm{~g} / \mathrm{kg}$ of vitamin E concentrate.

Carnosic acid is not an EO, but a phenolic diterpene extracted from Rosmarinus officinalis that acts as an antioxidant, it can be used in lamb diets high in concentrates to correct metabolic acidosis, because carnosic acid helps to maintain a stable acid-base balance at cellular level (Morán et al 2012, Morán et al 2013).

\section{CONCENTRATED FORAGES}

Finalisation of cattle with high energy diets reduces the cost per animal and reduces the feeding time, high weight gains are also obtained. However, these rations increase the incidence of acidosis (Anderson 1982), therefor it is necessary to include forages in ruminant finishing diets.

The decrease in the percentage of concentrates highly fermentable in feedlot diets, and when the level of forage is increased, the incidence of ruminal acidosis can decrease but these strategies are usually impractical for economic reasons, due to a decrease in feed efficiency (Krause 2002).

Ruminants need an adequate amount of fibrous texture food to prevent metabolic disorders. The level of fiber and large particles of food necessary to maintain rumen health depend on both the source and the size (NRC 2001). To prevent acidosis in sheep, a $30 \%$ of NDF is recommended (Lean et al 2007) and for dairy cattle at least $25 \%$ of NDF is recommended in the total diet on a dry basis, and $75 \%$ of this contribution must come from roughage to maintain a functional and healthy rumen (Li et al 2014). In dairy goats, between 373 and $384 \mathrm{~g} / \mathrm{kg}$ NDF of dry matter must be used to prevent acidosis problems (Sudweeks et al 1981). In lambs fed high concentrate diets, the use of 10 to $34.5 \%$ soybean hulls in the ration maintain a stable ruminal $\mathrm{pH}$ of 5.96 to 6.18 , being a major source of FND (Ferreira et al 2011).
In goats, when making the change from forage to concentrate from 70:30 to 30:70, the nutrient digestibility was better for rations with grains, compared to legumes. The ruminal $\mathrm{pH}$ of the 70:30 diet was 6.43 and the 30:70 diet was 6.21 (Cantalapiedra-Hijar et al 2009). In goat kids on finalisation fed diets with forage concentrate ratios of $60: 40,45: 55,30: 70$ and 15:85, ruminal $\mathrm{pH}$ was 6.92 , $6.15,6.32$ and 6.09 , respectively, therefore the proportion forage-concentrate maintaining adequate ruminal $\mathrm{pH}$ without affecting productive performance was 30:70 (Haddad 2005). In dairy goats fed a 50:50 forage-concentrate ration, in which three food particle sizes (1.81, 1.43 and $1.2 \mathrm{~mm}$ ) were evaluated and the NDF was effective, the ones fed $1.43 \mathrm{~mm}$ particles, VFA concentration was increased without affecting NDF degradability and cellulolytic bacteria growth, rumen $\mathrm{pH}$ was 6.04 (Li et al 2014).

In highly productive dairy cows, it is recommended to use $31.2 \%$ effective NDF and particle sizes greater than $1.18 \mathrm{~mm}$, or $18.5 \%$ effective NDF with particle sizes larger than $8 \mathrm{~mm}$ (Zebeli et al 2012).

Ruminal acidosis can be reduced by increasing the content of NDF physically effective in the diet, either by the use of long chopped forage or fodder proportion increase in the diet (Yang and Bauchemin 2006). Forage large particles promote rumination and secretion of saliva, which help to buffer acidity resulting from starch fermentation (Dijkstra et al 2012, Gonzalez et al 2012.). In cows, it has been demonstrated a close relationship between ruminal $\mathrm{pH}$ with respect to NDF content of the diet (32.2\%) and the average size of the food particles $(2.59 \mathrm{~mm})$, decreasing the content of FND below $32.2 \%$ and particle sizes smaller than $2.59 \mathrm{~mm}$ the rumen $\mathrm{pH}$ decreases and the joint effect of NDF and the particle size is increased when the rumen $\mathrm{pH}$ is lower than 6.0 (Sauvant and Mertens 2001).

Beet pulp is a byproduct of industrial sugar extraction and the main components are carbohydrates. It contains 25 to $45 \%$ NDF, barely lignified (1.7\%) plus appreciable quantities of pectins $(20 \%)$ and sugars $(6 \%)^{1}$. Pectin fermentation in the rumen does not generate lactic acid; galacturonic acid in its structure provides a buffer potential through the cation exchange and the bonding with a metal ion, so that the pulp helps regulate ruminal $\mathrm{pH}$ in concentrated rations of highly productive animals (Fernandez 2006, Bodas et al 2007).

The inclusion of pulp in cereal based diets of feedlot lambs seems to improve the ruminal environment and prevents ruminal acidosis, but has a negative effect on feed intake and animal behaviour (Fernandez 2006).

The fibrous texture of the food is quantitatively reflected on the ruminant mastication activity, stimulating the production of saliva which contains buffer substances, promoting the stability of the ruminal ecosystem. The appropriate size of feed particles for cows to maintain

FEDNA. 2012. Pulpa de remolacha (actualizado) nov. 2012, www fundaciónfedna.org; fecha de acceso 15.04.2014. 
unchanged rumination should be between 2.83 and 3.29 mm (Grant et al 1990).

Ruminal papillae are modified according to the ration ingested by dairy cows, decrease their size when receiving high forage (dry period), and increase in size when increasing the amount of fermentable carbohydrates in the rumen, which corresponds to the transition period, the increased size of ruminal papillae favours the absorption of volatile fatty acids and is involved in the regulation of ruminal $\mathrm{pH}$ (Liebich et al 1987).

The effect of the inclusion of forage and concentrate in granules of a size $4 \times 10 \mathrm{~mm}$ in whole rations for lambs in finalisation and its effect on the productive performance was demonstrated by Blanco et al (2014 $\left.{ }^{\mathrm{a}}\right)$ and Blanco et al $\left(2014^{b}\right)$ who found a better productive performance in lambs receiving the whole ration with the inclusion of up to $250 \mathrm{~g} / \mathrm{kg}$ dry matter of barley straw in the granule, than those who received separately barley straw and concentrate.

\section{TYPES OF CEREALS AND HOW TO MANAGE THE GRAIN}

The starch of grains is the most abundant energy source for productive livestock (Svikus et al 2005). Chemical structure has a linear (amylose) and a branched fraction (amylopectin) as different molecular types: amylose with $\alpha 1,4$ links and amylopectin with $\alpha 1,6$ links (French 1973, Huntington 1997). Starch is the major component of energy in grains: wheat contains $77 \%$ dry matter as starch, corn and sorghum $72 \%$, and barley and oats 57 to 58\% (Waldo 1973).

The starch in the rumen is first degraded by microorganism fermentation to produce VFA; also a small portion is degraded in the small intestine (Theurer et al 1999). The highest total starch digestibility of the diet occurs when the portion digested in the rumen is maximized and the fraction digested in the small intestine is minimized (Boyles et al 2015).

Starch digestion in the rumen differs between cereals, grouped from high to low digestibility as follows: oats, wheat, barley, corn and sorghum (Herrera-Saldana et al 1990, Tomankova and Homlka 2004) and the average ranking of grains for the risk of acidosis is: wheat, tritricale, barley, oats and sorghum, the risk factor was obtained by the disappearance of in saco starch, the production of lactic acid in vitro, as well as the starch content in the grain (Lean et al 2013).

Barley has a relatively fast ruminal fermentation of starch, and for the maximum efficiency rumen acidity must be maintained at an optimum $\mathrm{pH}$ range of 5.8 and 6.0 (AARD 2000, Nikkah 2012). Digestibility of the whole barley grain can be 10 to $25 \%$ lower than the one crushed by dry air. The one crushed by steam, uses moisture, heat and pressure to gelatinize the starch granules (Dehghanbanadaky et al 2007). The treatment of barley grain with $10 \mathrm{~g} / \mathrm{lactic}$ acid/L of water and heated at $55^{\circ} \mathrm{C}$ has multiple beneficial effects: rumen $\mathrm{pH}$ is $>5.8$ in the most intensive stage of fermentation, this $\mathrm{pH}$ stability prevents SARA and increases the fat content in milk (Iqbal et al 2012).

The particle size of the flakes steamed did not affect cattle behaviour; density of the flakes is the most important factor affecting the availability of starch in corn, the best density is $335 \mathrm{~g} / \mathrm{L}$ (Sendi et al 2006, Hales et al 2012). The flake density reduction decreases linearly the amount of starch flowing into the small intestine (Boyles et al 2015). Cornflakes with a density of $335 \mathrm{~g} / \mathrm{L}$, when combined with $6 \%$ alfalfa, can produce optimal behaviour of the animal with a limited risk of altering the acid-base balance; in feedlot cattle adapted to high grain diets, ruminal $\mathrm{pH}$ increases with the increasing bulk density of the flakes (Hales et al 2012).

\section{ADAPTATION PERIOD AND FEEDING FREQUENCY}

Another way to prevent lactic acidosis in ruminants is through a period of adaptation to the new diet from forage to concentrate. Feed changes from forage to concentrate or to whole diets must be done gradually and preferably within 2 to 3 weeks (Pugh 2002) to allow rumen microorganisms to adapt to new substrates, the ruminal epithelium to modify and ruminal homeostasis maintained (Liebich et al 1987). The adaptation of feedlot cattle to percentage increases of the concentrate in the diet, about 55-90\% of the dry matter of the diet, can be carried out in 14 days while the ad libitum food intake usually results in a reduction of the behaviour during the adaptation or in the entire period of finalisation (Brown et al 2006). In intensive lamb fattening systems, feeding is performed without restriction, lambs should always have food available in the feeders; if it is not possible to supply the food ad libitum it is advisable to feed twice a day, once in the morning and another in the afternoon.

When comparing two periods of adaptation, a long period of adaptation of $34 \mathrm{~d}$ and a short one of $8 \mathrm{~d}$, ruminal acidosis was induced by restricting food intake to $50 \%$ of the dry matter intake according to body weight for 24 hours, followed by intraruminal infusion of ground barley. Regression analysis confirms that the heifers exposed to the long period of adaptation, experienced a rapid linear recovery of ruminal $\mathrm{pH}$ with respect to time of the induced acidosis (Schwaiger et al 2013).

Sheep that are fed ad libitum spend more time with ruminal $\mathrm{pH}<5.6$ than when food was provided on a schedule at 8:00 and 16:00 (7.77 vs 3.05 hours/day). The time spent with ruminal $\mathrm{pH}<5.6$ was mainly linked to the amount of food intake. The time to recover the ruminal $\mathrm{pH}$ to optimum condition was longer in the ad libitum diet (Communs et al 2009).

The period of adaptation of ruminants to a high concentrate diet should be managed gradually to prevent acidosis. In finishing steers two periods of adaptations were evaluated rapid $v s$ gradual ( $3 v s 15$ days). In the gradual adaptation, the percentage of concentrate in the diet increased from 40 to $90 \%$, starting with values: $48.3,56.7,65.0,73.3$ and 81.7 for three days each of the percentages and at the end of 15 
days, they were given the finishing diet of $10 \%$ forage and $90 \%$ concentrate, proving that the gradual change in diet prevents cases of acidosis (Bevans et al 2005).

\section{CONCLUSIONS}

Ruminal acidosis is a metabolic disorder of ruminants fed high grain rations, with small particle size and deficient in fiber, it can also occur because of errors in nutritional management. It can be prevented by the inclusion in the diet of buffer substances, zootechnical additives, essential oils and antioxidants. Rations must be whole with a minimum amount of $32 \% \mathrm{NDF}$, food particle size suitable from 2.83 to $3.29 \mathrm{~mm}$. Slow degradation cereals should be used in the rumen as corn and sorghum, the grain must be processed by steam in the form of flakes. The change of forage to concentrate in the diet should be carried out gradually for at least 15 days. Animal welfare and production is improved, by preventing ruminal acidosis.

\section{REFERENCES}

Anderson VL. 1982. Limestone as a buffer in finishing rations. Farm Research 4, 7-8.

AARD, Alberta Agriculture and Rural Development. 2000. Nutrition and management of common feed grain. $2^{\text {nd }}$ ed. Alberta, Canada.

Aschenbach JR, Penner GB, Stumpff F, Gabel G. 2011. Ruminant Nutrition Symposium: Role of fermentation acid absorption in the regulation of ruminal pH. J Anim Sci 89, 1091-1107.

Askar AR, Guada JA, González JM, de Vega A, Castrillo C. 2011. Effects of sodium bicarbonate on dieta selection and rumen digestion by growing lambs individually fed whole barley grain and protein supplement at their choice. Animal Feed Science and Technology $164,45-52$.

Bach A, Iglesias D, Devant M. 2007. Daily rumen pH pattern of loosehoused dairy cattle as affected by feeding pattern and live yeast supplementation. Anim Feed Sci Tech 136, 146-153.

Bevans D, Beauchemin K, Schwartzkof-Genswein K, Mckinnon J, Mcallister T. 2005. Effect of rapid or gradual grain adaptation on subacute acidosis and feed intake by feedlot cattle. J Anim Sci 83, 1116-1132.

Blanch M, Calsamiglia S, Di-Lorenzo N, Di-Costanzo A, Muetzel S, et al. 2009. Physiological changes in rumen fermentation during acidosis induction and its control using multivalent polyclonal antibody preparation in heifers. J Anim Sci 87, 1722-1730.

Blanco C, Bodas R, Prieto N, Andrés S, López S, et al. 2014ª . Concentrate plus ground barley straw pellets can replace conventional feeding systems for light fattening lambs. Small Ruminant Res 116, 137-143.

Blanco C, Giráldez F, Prieto N, Benavides J, Wattegedera S, et al. 2014 ${ }^{\text {b }}$ Total mixed ration pellets for light fattening lambs: effects on animal health. Animal Consortion, 1-9.

Bodas R. 2004. El bicarbonato sódico en la alimentación de corderos en la etapa de crecimiento-cebo y de las ovejas en lactación. Tesis $P h D$, Universidad de León, León, España.

Bodas R, Giráldez F, Rodríguez A, Mantecón A. 2007. Inclusion of sugar beet pulp in cereal based diets for fattening lambs. Small Ruminant Res 71, 250-254.

Bolton J, Pass D. 1998. The alimentary tract. In: Robinson WF, Huxtable CRR (ed). Clinic pathologic principles for veterinary medicine. Cambridge University Press, Cambridge, UK, Pp 99-121.

Boyles S, Anderson V, Koch K. 2015. Feeding barley to cattle beef. Ohio State University Extension, Ohio, USA.
Brossard L, Martin C, Michalet-Doreau B. 2003. Ruminal fermentative parameters and blood acid-basic balance changes during the onset and recovery of induced latent acidosis in sheep. Anim Res 51, 513-530

Brown M, Krebhiel C, Galyean M, Remmenga M, Peters J, et al. 2000. Evaluation of model of acute and subacute acidosis on dry matter intake, ruminal fermentation, blood chemistry, and endocrine profiles of beef steers. J Anim Sci 78, 3155-3169.

Brown M, Ponce C, Pulikanti R. 2006. Adaptation of beef cattle to high-concentrate diets: Performance and ruminal metabolism. J Anim Sci 84, E25-E33.

Caja G, González E, Flores C, Carro M, Albanell E. 2003. Alternativas a los antibióticos de uso alimentario en rumiantes: probióticos, enzimas y ácidos orgánicos. FEDNA XIX Curso de especialización, Madrid, España.

Calsamiglia S, Blanch M, Ferret A, Moya D. 2012. Is subacute acidosis a pH related problem? Causes and tools for its control. Anim Feed Sci Tech 172, 42-50.

Calsamiglia S, Cardozo P, Ferret A, Bach A. 2008. Changes in rumen microbial fermentation are due to a combined effect of type of diet and pH. J Anim Sci 86, 702-711.

Cantlapiedra-Hijar G, Yáñez-Ruiz R, Martín-García A, Molina-Alcaide E. 2008. Effects of forage:concentrate ratio and forage type on apparent digestibility, ruminal fermentation, and microbial growth in goats. J Anim Sci 87, 622-631.

Cardozo P, Calsamiglia S, Ferret A, Kamel C. 2005. Screening for the effects of natural plant extracts at different $\mathrm{pH}$ in vitro rumen microbial fermentation of a high concentrate diet for beef cattle. J Anim Sci 83, 2572-2579.

Cardozo P, Calsamiglia S, Ferret A, Kamel C. 2006. Effects of alfalfa extract, anise, capsicum, and a mixture of cinnamaldehyde and eugenol on ruminal fermentation and protein degradation in beef heifers fed high-concentrate diet. J Anim Sci 88, 2801-2808.

Carenzi C, Verga M. 2009. Animal welfare: review of the scientific concept and definition. Review Article. Ital J Anim Sci 8, 21-30.

Castillejos L, Calsamiglia S, Martin-Tereso J, Ter-Wijlen H. 2008. In vitro evaluation of effects of ten essential oils at three doses on ruminal fermentation of high concentrate feedlot-type diets. Anim Feed Sci Tech 155, 259-270.

Castillo-López E, Wiese B, Hendrick S, Mckinnon J, Mcallister T, et al. 2014. Incidence, prevalence, severity and risk factors for ruminal acidosis in feedlot steers during back grounding diet transition, and finishing. J Anim Sci 92, 3053-3063.

Céspedes M. 2012. Efecto de la vitamina E en el crecimiento y en la calidad de la canal y de la carne en corderos ligeros. Disertación $M S c$, Universidad de Zaragoza, Zaragoza, España.

Clark J, Christensen R, Bateman H, Cummings K. 2009. Effects of sodium sesquicarbonate on dry matter intake and production of milk and milk components by Holstein cows. J Dairy Sci 92, 3354-3363.

Cobos M, Ley de Coss A, Ramírez N, González S, Ferrera Cerrato R. 2011. Pediococcus acidilactic isolated from the rumen of lambs with rumen acidosis, 166 rRNA identification and sensibility to monensin and lasalocid. Res Vet Sci 90, 26-30.

Communs L, Mialon MM, Martin C, Baumont R, Veissier I. 2009. Risk of subacute ruminal acidosis in sheep with separate access to forage and concentrate. J Anim Sci 87, 3372-3371.

Dehghan-Banadaky M, Corbett R, Oba M. 2007. Effects of barley grain processing on productivity of cattle. Anim Feed Sci Tech 137, 1-24.

Dijkstra J, Ellis J, Kebrab E, Strathe A, Lopez S, et al. 2012. Ruminal $\mathrm{pH}$ regulation and nutritional consequences of low $\mathrm{pH}$. Anim Feed Sci Tech 172, 22-23.

Erdman R. 1998. Dietary buffering requirements of the lactating cows: a review. J Dairy Sci 71, 3246-3266.

Fernández D. 2006. Empleo de la pulpa de remolacha en la alimentación del ganado ovino. PhD Dissertation, Universidad de León, León, España.

Ferreira E, Pires A, Susin I, Mendes C, Queiroz M, et al. 2011. Apparent digestibility, nitrogen balance, and ruminal constituents in ram 
lambs fed high-concentrate diets containing soybean hulls. J Anim Sci 89, 4127-4133.

French D. 1973. Chemical and physical properties of starch. J Anim Sci 37, 1048-1064.

Foskolos A, Siurana A, Rodriguez-Prado M, Ferret A, Bravo D, et al. 2015. The effect of a garlic oil chemical compound, propyl-propane thiosulfate, on ruminal fermentation and fatty acid outflow in a dual-flow continuous culture system. J Dairy Sci 98, 5482-5491.

Fulton W, Klopfenstein T. 1979. Adaptation to high concentrate diets by beef cattle. II. Effect of ruminal $\mathrm{pH}$ alteration on rumen fermentation and voluntary intake of wheat diets. J Anim Sci 48, 785-789.

Galyean M, Rivera J. 2003. Nutritionally related disorders affecting feedlot cattle. Can J Anim Sci 83, 13-20.

Garret E, Pereira M, Nordlund K, Armentano L, Goodger W, et al. 1999. Diagnostic methods for the detection of subacute ruminal acidosis in dairy cows. J Dairy Sci 82, 1170-1178.

Gastaldello A, Pires A, Susin I, Mendes C, Quiroz M, et al. 2013. Limestone with different particle size and sodium bicarbonate to feedlot lambs fed high grain diets with or without monensin. Small Ruminant Res 114, 80-85.

Giger-Reverdin S, Desnoyers M, Duvaux-Ponter R, Sauvant D. 2006. TI72 Rumen and metabolic acidosis in dairy goats are independent. J Anim Sci 84, 215.

González L, Manteca X, Calsamiglia S, Schwartzkopf-Genswein K, Ferret A. 2012. Ruminal acidosis in feedlot cattle: Interplay between feed ingredients, rumen function and feeding behavior (a review). Anim Feed Sci Tech 172, 66-79.

Grant R, Colenbrander V, Mertens D. 1990. Milk fat depression in dairy cows role of silage particle size. J Dairy Sci 73, 1834-1842.

Hadad S. 2005. Effect of dietary forage:concentrate ratio on growth performance and carcass characteristics of growing Baladi kids. Small Ruminant Res 57, 43-49.

Haji-Hajikolaei M, Mouri M, Saberi-Afshar F, Jafari-Dekkordi A. 2006. Effects of experimentally induced ruminal lactic acidosis on blood pH, bicarbonate and pCO2 in the sheep. Pakistan Journal of Biological Sciences 9, 2005-2005.

Hales K, Meniman J, Leibovich J, Vasconcelos J, Quinn M, et al. 2012. Effects of varying bulk densities of steam flaked corn and dietary concentration on in vitro fermentation, performance, carcass quality, and acid-base balance measurements in finishing steers. J Anim Sci 88, 1135-1147

Harmon D, Britton R, Prior R, Stock R. 1985. Net portal absorption of lactate and volatile fatty acids in steers experiencing glucose-induced acidosis or fed a $70 \%$ concentrate diet ad libitum. J Anim Sci 60, 560-569.

Hashemi M, Zamani F, Vatankhah M, Hossein-Zadeh S. 2012. Effect of sodium bicarbonate and magnesium oxide on performance and carcass characteristics of Lori-Bakhtiari fattening lambs. Global Veterinaria 8, 89-92.

Henning P, Horn C, Leeuw K, Meissner H, Hagg F. 2010. Effect of ruminal administration of the lactate utilizing strain Megasphaera elsdenii (Me) NCIMB41125 on abrupt or gradual transition from forage to concentrate diets. Anim Feed Sci Tech 157, 20-29.

Henning P, Horn C, Stein D, Meissner H, Hagg F. 2010. The potential of Megasphaera elsdenii isolates to control ruminal acidosis. Anim Feed Sci Tech 157, 13-19.

Hernández J, Benedito J, Abuelo A, Castillo C. 2014. Ruminal acidosis in feedlot: from aetiology to prevention. The Scientific World Journal, ID 702572.

Herrear-Saldaña R, Huber J, Poore M. 1990. Dry matter, crude protein, and starch degradability of five cereal grains. J Dairy Sci 73, 2386-2393.

Hewson J. 2003. What is animal welfare? Common definition and their practical consequences. Can Vet J 44, 496-499.

$\mathrm{Hu}$ W, Murphy M. 2005. Statistical evaluation of early and mid lactation dairy cow responses to dietary sodium bicarbonate addition. Anim Feed Sci Tech 119, 43-54.

Huber T. 1976. Physiological effects of acidosis on feedlot cattle. J Anim Sci 43, 902-909.
Huntington G. 1997. Starch utilization by ruminants: from basic to the bunk. J Anim Sci 75, 852-857.

Iqbal S, Terril S, Zebeli Q, Mazzolari A, Dunn S, et al. 2012. Treating barley grain with lactic acid and heat prevented sub-acute ruminal and increased milk fat in dairy cows. Anim Feed Sci Tech 172, 141-149.

Kirbas A, Yildirim A, Baydar E, Kandemir M. 2014. Status of lipid peroxidation and some antioxidants in sheep with acute ruminal lactic acidosis. Medycyna Weterynaryjna 70, 357-361.

Kleen J, Cannizzo C. 2012. Incidence, prevalence and impact of SARA in dairy herds. Anim Feed Sci Tech 4, 4-8.

Kohn R, Dunlap T. 1998. Calculation of the buffering capacity of bicarbonate in the rumen an in vitro. J Anim Sci 76, 1702-1709.

Krause K, Oetzel G. 2006. Understanding and preventing subacute ruminal acidosis in dairy herds: A review. Anim Feed Sci Tech 126, 215-236.

Krause K, Combs D, Beauchemin K. 2002. Effects of forage particle size and grain fermentability in mid lactation cows. II Ruminal $\mathrm{pH}$ and chewing activity. J Dairy Sci 85, 1947-1957.

Laskoski M, Muraro S, Santana-Junior S, Carvalho B, Freitas H, et al. 2014. Sodium bicarbonate as prevention of metabolic acidosis in sheep submitted to experimental ruminal acidosis. Pesqui Vet Brasil 34, 822-826

Lean I, Annison F, Bramley E, Browning C, Cusack P, et al. 2007. Ruminal acidosis-understandings, prevention and treatment. A review for veterinarians and nutritional professionals. Australian Veterinary Association 3, 46.

Lean I, Golder H, Black J, King R, Rabiee A. 2013. In vivo indices for predicting acidosis risk of grain in cattle: Comparison with in vitro methods. J Anim Sci 91, 2823-2835.

Lettat A, Mozieré P, Silbeerberg M, Morgavi D, Berger C, et al. 2010. Experimental feed induction of ruminal lactic, propionic, o butyric acidosis in sheep. J Anim Sci 88, 3041-3046.

Li F, Yang X, Cao Y, Li S, Yao J, et al. 2014. Effects of dietary effective fiber to rumen degradable starch rations on the risk of sub-acute ruminal acidosis and rumen content fatty acids compositions in dairy goat. Anim Feed Sci Tech 189, 54-62.

Liebich H, Derksen G, Arbel E, Dori S, Mayer E. 1987. Fütterungsabhängige Veränderungen der Pansenschleimhaut von Hochleistungskü her im Zeitraum von der trockenstellung bin acht Wochen post partum. $J$ Vet Med 34, 661-672.

Maulfair D, Mcintyre K, Heinrichs A. 2013. Subacute rumial acidosis and total mixed ration preference in lactating dairy cows. J Dairy Sci 96, 6610-6620.

Meschy F, Bravo D, Sauvant D. 2004. Analyse quantitative des response des vaches laitieres á l'apport de substances tampon. Prod Anim 17, 11-18.

Minuti A, Ahmed S, Trevisi E, Piccioli-Capelli F, Bertoni G, et al. 2014. Experimental acute acidosis in sheep. Consequences on clinical, rumen, and gastrointestinal permeability conditions and blood chemistry. J Anim Sci 92, 3966-3077.

Morán L, Giráldez F, Bodas R, Benavides J, Prieto N, et al. 2013. Metabolic acidosis corrected by including antioxidants in the diet of fatting lambs. Small Rumin Res 109, 133-135.

Morán L, Andrés S, Bodas R, Benavides J, Prieto N, et al. 2012. Antioxidants included in the diet of fattening lambs: Effects on inmune response, stress, welfare and distal gut microbiota. Anim Feed Sci Tech 173, 177-175.

Nikkah A. 2012. Barley grain for ruminants: A global treasure or tragedy. J Anim Sci Biotechno 3, 1-22.

Nocek J. 1997. Bovine acidosis: implications on laminitis. J Dairy Sci 80, 1005-1028.

NRC, National Research Council. 2001. The nutrient requirements of dairy cattle. $7^{\text {th }} \mathrm{ed}$. National Academies Press, Washington, DC, USA.

Oba M, Wertz-Lutz A. 2011. Ruminant nutrition symposium: Acidosis, new insights into the persistent problem. J Anim Sci 89, 1090-1091.

Odongo N, Alzahal O, Lindenger M, Duffield T, Valdes E, et al. 2006 . Effects of mild heat stress and grain challenge on acid-base balance and rumen tissue histology in lambs. J Anim Sci 84, 447-455. 
Odongo N, Las J, Wadud S, Aizahal O, Lindinger M, et al. 2006 ${ }^{\mathrm{b}}$. T173 Effects of chronic metabolic acidosis on acid-base balance and plasma free amino acids in lambs. J Anim Sci 84, 215.

Patra R, Lal S, Swarup D. 1991. Physicochemical alterations in blood cerebrospinal fluid and urine in experimental lactic acidosis in sheep. Res Vet Sci 54, 217-22.

Penner G, Aschenbach J, Gäbel G, Oba M. 2009. Technical note: Evaluation of a continuous $\mathrm{pH}$ measurement system for use in noncanulated small ruminants. J Anim Sci 87, 2363-2366.

Penner G, Oba M, Gäbel G, Aschenbach J. 2010. A single mild episode of subacute ruminal acidosis does not affect ruminal barrier function in short term. J Dairy Sci 93, 4838-4845.

Penner G, Steel M, Aschenbach J, Mcbride B. 2011. Ruminant Nutrition Symposium: Molecular adaptation on ruminal epithelia to highly fermentable diets. J Anim Sci 89, 1108-1119.

Plaizer J, Khafipours E, Li S, Gozho G, Krause D. 2012. Subacute ruminal acidosis (SARA) endotoxin and health consequences. Anim Feed Sci Tech 171, 9-21.

Pugh D. 2002. Sheep and Goat Medicine. $1^{\text {st }}$ ed. Saunders, Philadelphia, USA.

Rauch R, Robinson P, Erasmus L. 2012. Effects of sodium bicarbonate and calcium magnesium carbonate supplementation on performance of high producing dairy cows. Anim Feed Sci Tech 177, 180-193.

Rustom B, Aizahal O, Cant J, Fan M, Duffield T, et al. 2006. T175 Effects of rumen acid-load from feeds on ruminal $\mathrm{pH}$, dry matter intake, fiber degradability and milk production in the lactating dairy cow. J Anim Sci 84, 216.

Sauvant D, Mertens D. 2001. Empirical modeling of ruminal $\mathrm{pH}$ from dietary NDF and mean particle size. J Anim Sci 79, 198-199, Suppl. 1, 105.

Sayago A, Marín M, Aparicio R, Morales M. 2007. Vitamina E y aceites vegetales. Grasas y Aceites 58, 74-79.

Schwaiger T, Bauchemin K, Penner G. 2013. The duration of time that cattle are fed a high-grain diet affects the recovery from a bout of ruminal acidosis. Dry matter intake and ruminal fermentation. J Anim Sci 91, 5729-5742.

Sendi J, Drouillerd J, Montgomery S, Loe E. 2006. Factors influencing characteristics of steam flaked and utilization by finishing cattle. J Anim Sci 84, 154-161.

Shu Q, Gill H, Leng R, Browe J. 2000. Inmunization with Streptococcus bovis vaccine administred by different routes against lactic acidosis in sheep. Vet $J 159,262-269$.

Smith R. 1998. Impact of diseases on feedlot performance: A review. J Anim Sci 76, 272-274.
Steel M, Alzahal O, Hook D, Croom J, McBride B. 2009. Ruminal acidosis and the rapid onset of ruminal parakeratosis in a mature dairy cow: a case report. Acta Vet Scand 51, 39.

Sudweeks E, Ely O, Mertens D, Sisk L. 1981. Assessing minimum amount and form of roughage in ruminant diets: roughage value index system. J Anim Sci 53, 1406-1411.

Svikus B, Uhlem A, Hastad O. 2005. Effect of starch granule structure, associated components and processing nutritive value of cereal starch: A review. Anim Feed Sci Tech 122, 303-320.

Theurer C, Lozano O, Aliv A, Delgado-Elorduy A, Sadik M, et al. 1999. Steam processed corn and sorghum grain flaked at different densities alter ruminal, small intestinal and total tract digestibility of starch by steers. J Anim Sci 77, 2824-2831.

Tománková $\mathrm{O}$, Homlka P. 2004. In vitro ruminal degradation of cereal grain starch. Czech Journal of Animal Science 49, 151-155.

Uyeno Y, Akiyama K, Hasunuma T, Yamamoto H, Yokokawa H, et al. 2017. Effects of supplementing an active dry yeast product on rumen microbial community composition and on subsequent rumen fermentation of lacting cows in the mid-to-late lactation period. Anim Sci J 88, 119-124.

Van Vuuren AD, Calsamiglia S, Udén P. 2012. Rumen health: A $360^{\circ}$ analysis. Anim Feed Sci Tech 172, 1-3.

Vyas D, Uwsvizeye A, Mohammed R, Yang WZ, Walker ND, et al. $2014^{\mathrm{a}}$. The effects of active dried, killed dried yeast on subacute ruminal acidosis, ruminal fermentation and nutrient digestibility in beef heifers. J Anim Sci 92, 724-732.

Vyas D, Uwsvizeye A, Yang WZ, Beauchemin KA. 2014 ${ }^{\text {b }}$. Importance of yeast viability for reducing the effects of ruminal acidosis in beef heifers during and following an imposed acidosis challenge. Anim Feed Sci Tech 197, 103-113.

Waldo DR. 1973. Extent and partition of cereal grain starch digestion in ruminants. J Anim Sci 37, 1062-1074.

Wenping H, Kung JL, Murphy MR. 2007. Relationship between dry matter intake and acid-base status of lacting dairy cows as manipulated by dietary cation-anion difference. Anim Feed Sci Tech 136, 216-225.

Yang Z, Beauchemin KA. 2006. T177 Effect of physically effective fiber on chewing and ruminal $\mathrm{pH}$ of dairy cows fed diets containing barley or corn grain. J Anim Sci 84, Suppl. 1, 215.

Zebeli Q, Aschenbach JR, Tafaj M, Boguhn J, Ametaj BN, et al. 2012. Role of physically effective fiber and estimation of dietary fiber adequacy in high-producing dairy cattle. J Dairy Sci 95, 1041-1056.

Zhao X, Zhang T, Xu M, Yao J. 2011. Effects of physically effective fiber on chewing activity, ruminal fermentation, and digestibility in goats. J Dairy Sci 89, 501-509. 